\title{
The Motor Coordination Activity Of Aqueous Extract Of Withania Coagulans Fruits In Swiss Albino Mice By Rota Rod Test
}

\author{
Amit S. Kamdi, Devesh D. Gosavi, Suvarna M. Kalambe, and Pankaj N. Bohra
}

\begin{abstract}
Background: The various sedative and hypnotic medications used today have the central nervous system (CNS) depressant effects. A very little work has been done on the Withania coagulans - a vulnerable species as it is not found rampant in the world except in late seventies. Therefore, it was important to explore the CNS depressant activities of aqueous extract of Withania coagulans fruits in Swiss albino mice by using rota rod test.

Methods: Motor coordination was assessed by using the Rota Rod Test. The CNS depressant drugs decrease the endurance time of mice on the rota rod as they impair the motor coordination so that mice fall early on the rotating rod. This endurance time is statistically correlated among the control, standard and the test drugs.

Results: There was statistically highly significant (p-value $<0.001)$ association observed between aqueous extract of Withania coagulans fruits with endurance time in Swiss albino mice on rota rod test.

Conclusion: The aqueous extract of Withania coagulans fruits demonstrated the CNS depressant activity in Swiss albino mice by rota rod test.
\end{abstract}

Index Terms - CNS depressant; rota rod test; Swiss albino mice (SAM); Withania coagulans.

\section{INTRODUCTION}

Insomnia is defined as the individual perception of trouble with sleep commencement, extent, consolidation, quality, which occurs in spite of adequate opportunity for sleep, thus results in daytime impairment [1]. Prevalence of insomnia in the world is $10-30 \%$ [2]-[4]. However, the prevalence of insomnia in India is 9\% in the general population [5].

There are various drugs like benzodiazepines and barbiturates used for the treatment of insomnia. However, these drugs are not devoid of the side effects. The Rota rod test is widely used to evaluate the motor coordination in rodents [6]. When a mouse is repeatedly placed on a rod or cylinder which is rotating at a constant speed, the animal gradually learns to walk on it, adapting itself to the rotation speed. After ingestion of a central depressant, however, the animal easily falls from the rod. This test was first introduced by Dunham and Miya for assaying the drug effects on the motor activity [7]. Since then, the effects of various central depressants, investigated by this test have been reported [8][10].

Withania coagulans is a rare species, not found rampant in the territory. It is distributed in east of the Mediterranean region extending to South Asia i.e. Iran, Afghanistan, Pakistan (Sind and Baluchistan), Nepal and India. In India, it is found in the North-West region mainly Himachal Pradesh (Simla), Uttarakhand (Garhwal \& Kumaon hills), Punjab, and Western Rajasthan (Barmer, Jaisalmer and Jodhpur districts) [11]. This plant is mainly used for the milk coagulation. Though lot of work has been done to explore its hypoglycemic activity, not much work is done to evaluate its action on the central nervous system [12]-[14]. In 1977 Budhiraja et.al. reported CNS depressant activity of this plant [15]. Thereafter this plant was not much explored for the CNS activity. Therefore, it was thought worthwhile to assess the CNS depressant action of this medicinal herb in Swiss albino mice by Rota rod test.

\section{MATERIALS AND METHODS}

\section{A. Rota Rod Test Apparatus}

The Rota rod consists of experimental compartments, with a common rotating rod of about $25 \mathrm{~mm}$ diameter with selectable speeds of approximately 5, 10, 15, 20 and 25 revolutions per minute. The interval counters are provided in each compartment. The apparatus works on 220/30 Volts, single phase, $50 \mathrm{~Hz}, \mathrm{AC}$. On the floor of each compartment there is a cantilever platform that is hinged at the rear end.

\section{B. Rota Rod Test Procedure}

The shaft's angular velocity was adjusted by changing the position of the Drive Belt, from one pair corresponding grooves to another. The shaft rotated in anticlockwise direction and such the animal in general fell on the front side of the platform i.e. towards the free end of the platform. In our experiment the shaft's angular velocity was adjusted to 25 revolutions per minute. On switching on, the counter showed some arbitrary reading as the counter was running i.e. counting. The counter was stopped by pressing the platform gently till the switch below it operated by making a click sound. The platform below it was raised gently making sure that the switch below it was released. The apparatus made ready to operate. Placing the mouse on the rotating shaft the RESET switch was simultaneously pressed. On pressing the RESET switch counter started counting the time in seconds. Regardless of the previous reading on the counter, the counter started counting from "zero" only. When animal fell off the 
rotating shaft on the platform, the platform was lowered down by the falling impact-stopping the counter. This showed the animal's endurance time in seconds. Endurance time is defined as the time period for which each mouse remained on the rotating rod during test session [16]. To restart the counter again for the next trial, the platform was lifted gently, animal was placed on the rotating rod and the RESET switch was pressed, so that the counter started. The Rota rod was designed for the normal rat of around $150 \mathrm{gm}$ in weight. Since the mice weight was much lower than that of rats, the difference of weight was added to the platform by putting securing weight with the help of adhesive tape at the front end of the platform. All the compartments were used simultaneously.

\section{Control, Standard and Test Drugs}

Distilled water was given as vehicle for control. Diazepam was used as the standard drug. The animals were treated 30 min before the experiment with the test drugs (WCFAqE of $200 \mathrm{mg} / \mathrm{kg}, 500 \mathrm{mg} / \mathrm{kg}$ and $1000 \mathrm{mg} / \mathrm{kg}$ doses p. о.). However, the test drug was given every day for 30 days throughout the period of experiment. The mice were observed for 5 min. Recordings were done on Day 1, Day 8, Day 15, Day 23 and Day 30 for all the groups. The recordings were taken half an hour after drug administration to the respective group. Drugs were given in the following manner:

Control: Vehicle (Distilled Water) $2 \mathrm{ml} / \mathrm{kg}$ p. o. once a day for 30 days.

Standard: Standard drug (Diazepam) $5 \mathrm{mg} / \mathrm{kg}$ i. p. once half an hour before test.

AQ-200: WCFAqE $200 \mathrm{mg} / \mathrm{kg}$ p. o. once a day for 30 days. AQ-500: WCFAqE $500 \mathrm{mg} / \mathrm{kg}$ p. o. once a day for 30 days. AQ-1000: WCFAqE $1000 \mathrm{mg} / \mathrm{kg} \mathrm{p}$. o. once a day for 30 days.

Where WCFAqE=Withania coagulans fruits aqueous extract.

\section{Conflict of Interest}

There is no conflict of interest among authors.

\section{E. Source of Support}

Mahatma Gandhi Institute of Medical Sciences (MGIMS), Sevagram.

\section{F. Ethical Approval}

Study was approved by Institutional as well as the Animal Ethics Committee of MGIMS, Sevagram.

\section{RESULTS}

As observed in the Table I, on Day 1 to Day 8 there was no statistically significant difference in endurance time by mice. However, on days 15, 23 and 30 endurance time by mice on rota rod apparatus decreased highly significantly $(\mathrm{p}<0.001)$ for all the three doses of $200 \mathrm{mg} / \mathrm{kg}, 500 \mathrm{mg} / \mathrm{kg}$ and 1000 $\mathrm{mg} / \mathrm{kg}$ of WCFAqE compared to control. Furthermore, dose response relationship was observed for these doses. To conclude, this decrease in endurance time by test drug was comparable to that of standard diazepam.
TABLE I: EFFECT OF ORAL ADMINISTRATION OF WCFAQE ON ENDURANCE TIME (MEAN \pm SD) OF MICE IN SECONDS IN ROTA ROD TEST

\begin{tabular}{|c|c|c|c|c|c|}
\hline & Control & Standard & $A Q-200$ & $A Q-500$ & $A Q-1000$ \\
\hline Day 1 & $\begin{array}{l}18.66 \\
\pm 9.11\end{array}$ & $\begin{array}{l}17.16 \\
\pm 8.08\end{array}$ & $\begin{array}{c}20.16 \\
\pm 11.58\end{array}$ & $\begin{array}{l}19.33 \\
\pm 8.35\end{array}$ & $\begin{array}{c}18.83 \\
\pm 10.94\end{array}$ \\
\hline Day 8 & $\begin{array}{c}17.83 \\
\pm 12.49 \\
\end{array}$ & $\begin{array}{r}12.50 \\
\pm 5.82 \\
\end{array}$ & $\begin{array}{l}16.33 \\
\pm 9.89 \\
\end{array}$ & $\begin{array}{c}15.16 \\
\pm 11.30\end{array}$ & $\begin{array}{c}14.66 \\
\pm 11.23 \\
\end{array}$ \\
\hline Day 15 & $\begin{array}{l}23.16 \\
\pm 3.86 \\
\end{array}$ & $\begin{array}{c}8.66 \\
\pm 2.58 * * * \\
\end{array}$ & $\begin{array}{c}10.33 \\
\pm 1.75^{* * *} \\
\end{array}$ & $\begin{array}{c}9.66 \\
\pm 4.13 * * * \\
\end{array}$ & $\begin{array}{c}9.00 \\
\pm 1.41 * * *\end{array}$ \\
\hline Day 23 & $\begin{array}{l}21.33 \\
\pm 2.42\end{array}$ & $\begin{array}{c}5.83 \\
\pm 1.94 * * *\end{array}$ & $\begin{array}{c}8.16 \\
\pm 2.56 * * *\end{array}$ & $\begin{array}{c}6.83 \\
\pm 1.94 * * *\end{array}$ & $\begin{array}{c}5.50 \\
\pm 1.37 * * *\end{array}$ \\
\hline Day 30 & $\begin{array}{l}19.50 \\
\pm 3.72\end{array}$ & $\begin{array}{c}3.50 \\
\pm 1.04 * * *\end{array}$ & $\begin{array}{c}6.00 \\
\pm 1.78^{* * *}\end{array}$ & $\begin{array}{c}5.00 \\
\pm 1.78 * * *\end{array}$ & $\begin{array}{c}4.50 \\
\pm 1.51 * * *\end{array}$ \\
\hline
\end{tabular}

$* \mathrm{p}<0.05, * * \mathrm{p}<0.01$ and $* * * \mathrm{p}<0.001$ compared to control group

WCFAqE: Withania coagulans fruits aqueous extract.

Control: Vehicle (Distilled Water) $2 \mathrm{ml} / \mathrm{kg} \mathrm{p}$. o. once a day for 30 days. Standard: Standard drug (Diazepam) $5 \mathrm{mg} / \mathrm{kg}$ i. p. half an hour before test. $A Q$-200: WCFAqE $200 \mathrm{mg} / \mathrm{kg}$ body weight $\mathrm{p}$. o. once a day for 30 days. $A Q$-500: WCFAqE $500 \mathrm{mg} / \mathrm{kg}$ body weight $\mathrm{p}$. o. once a day for 30 days. $A Q$-1000: WCFAqE $1000 \mathrm{mg} / \mathrm{kg}$ body weight $\mathrm{p}$. o. once a day for 30 days.

\section{DISCUSSION}

In our study as observed in Table I, on days 15, 23 and 30 endurance time by mice on rota rod apparatus "decreased" highly significantly $(\mathrm{p}<0.001)$ for all the three doses of $200 \mathrm{mg} / \mathrm{kg}, 500 \mathrm{mg} / \mathrm{kg}$ and $1000 \mathrm{mg} / \mathrm{kg}$ of WCFAqE compared to control. Furthermore, dose response relationship was observed for this 'decrease'.

Our study is exceptional one as there are no other studies reported which have tested the effect of any of the extract of Withania coagulans on mice using Rota rod apparatus. Yet, Withania somnifera (WS) which is a similar species as that of Withania coagulans (WC) had been tested for the motor coordination using Rota rod apparatus in middle cerebral artery occluded (MCAO) rodents. It was found that WS had significantly $(\mathrm{p}<0.05)$ "increased" the performance of MCAO rodents treated with WS root extract on Rota rod apparatus [17]. Hence it can be concluded that the different withanoloides in both the species might be responsible for this activity.

There are two types of Rota rod test. One is the constant speed Rota rod, and another is the accelerating Rota rod [18]. In our study we used the constant speed Rota rod apparatus. But it has few drawbacks. Rod's diameter can influence the performance of mice [19], therefore we used Rota rod of 25 mm diameter. The drug to be tested can affect the memory of mice rather than the motor coordination [20], to eradicate this bias we trained the mice vigorously before test. The constant speed Rota rod are time consuming because the time limit needs to be set which decreases the sensitivity of this test [20]. To eliminate this bias, we used the maximum velocity of $25 \mathrm{rpm}$ on the Rota rod test which had a range of 5 to $25 \mathrm{rpm}$. The maximum endurance time of mouse on this apparatus was 38 seconds. This test can evaluate the muscle relaxant property of any compound but does not really differentiate between anxiolytics and neuroleptics. Usually, the central depressant drugs have muscle relaxant activity. Therefore, this test can be useful to assess the central depressive effect of any drug [7].

It has been proved that the stimulants increase the performance of mice on the Rota rod test so that mice take longer time to fall from the rotating rod [10]. On the other hand CNS depressants decrease the endurance time of mice 
on Rota rod so that mice fall early on rotating rod [21] Therefore, we can conclude that our test drugs WCFAqEs might have depressant activity on mice. Since the effect appeared after 15 days, it cannot be used in the acute settings. Hence it is more suitable for the chronic conditions.

\section{CONCLUSION}

In conclusion the test drugs WCFAqEs if administered in chronic settings might have CNS depressant activity on mice.

\section{REFERENCES}

[1] A. S. D. Association, (1997) "International classification of sleep disorders. Revised: Diagnostic and coding manual,", Academy of Sleep Medicine. [Online]. Available: http://www.absm.Org/PDF/ICSD.Pdf.

[2] D. J. Buysse, J. Angst, A. Gamma, V. Ajdacic, D. Eich, and W. Rössler, "Prevalence, course, and comorbidity of insomnia and depression in young adults," Sleep, vol. 31, no. 4, pp. 473-480, 2008.

[3] S. Schutte-Rodin, L. Broch, D. Buysse, C. Dorsey, and M. Sateia, "Clinical guideline for the evaluation and management of chronic insomnia in adults”, J. Clin. Sleep Med., vol. 4, no. 5, pp. 487-504, 2008.

[4] D. J. Taylor, L. J. Mallory, K. L. Lichstein, H. H. Durrence, B. W. Riedel, and A. J. Bush, "Comorbidity of chronic insomnia with medical problems", Sleep, vol. 30, no. 2, pp. 213-218, 2007.

[5] S. Panda, A. B. Taly, S. Sinha, G. Gururaj, N. Girish, and D. Nagaraja, "Sleep-related disorders among a healthy population in South India", Neurol. India, vol. 60, no. 1, p. 68, 2012.

[6] H. Shiotsuki et al., "A rotarod test for evaluation of motor skill learning”, J. Neurosci. Methods, vol. 189, no. 2, pp. 180-185, 2010.

[7] N. W. Dunham and T. S. Miya, "A note on a simple apparatus for detecting neurological deficit in rats and mice", J. Am. Pharm. Assoc., vol. 46, no. 3, pp. 208-209, 1957.

[8] W. J. Kinnard Jr and C. J. Carr, "A preliminary procedure for the evaluation of central nervous system depressants", J. Pharmacol. Exp. Ther., vol. 121 , no. 3 , pp. 354-361, 1957.

[9] M. I. Gluckman, "Pharmacology of oxazepam (Serax), a new antianxiety agent", Curr. Ther. Res. Clin. Exp., vol. 7, no. 11, p. 721, 1965.

[10] N. Plotnikoff, D. Reinke, and J. Fitzloff, "Effects of stimulants on rotarod performance of mice", J. Pharm. Sci., vol. 51, no. 10, pp. 1007-1008, 1962.

[11] I. Pandey and K. S. Nama, "Withania Coagulans (Stocks) Dunal - A Rare Ethnomedicinal Plant of the Western Rajasthan Desert", Int. J. Phar. \& Biomedi. Rese, vol. 2, no. 2, pp. 34-40, 2015.

[12] S. B. Meeran, U. Subburaya, and G. Narasimhan, "In Silico and In Vitro Screening of Ethanolic Extract of Fruits of Withania Coagulans against Diabetes", Res. J. Pharm. Technol., vol. 13, no. 2, pp. 631-635, 2020.

[13] S. Ojha et al., "Withania coagulans fruit extract reduces oxidative stress and inflammation in kidneys of streptozotocin-induced diabetic rats", Oxid. Med. Cell. Longev., vol. 2014, no. October 2015, 2014.

[14] S. Hemalatha, A. K. Wahi, P. N. Singh, and J. P. N. Chansouria, "Hypoglycemic activity of Withania coagulans Dunal in streptozotocin induced diabetic rats", J. Ethnopharmacol., vol. 93, no. 2-3, pp. 261-4, Aug. 2004.

[15] R. D. Budhiraja, S. Bala, and K. N. Garg, "Pharmacological investigations on fruits of Withania coagulans, Dunal", Planta Med., vol. 32, no. 2, pp. 154-7, Sep. 1977.

[16] J. F. Cryan et al., "Behavioral characterization of the novel GABAB receptor-positive modulator GS39783 (N, N'-dicyclopentyl-2methylsulfanyl-5-nitro-pyrimidine-4, 6-diamine): anxiolytic-like activity without side effects associated with baclofen or benzodiazepines", $J$. Pharmacol. Exp. Ther., vol. 310, no. 3, pp. 952-963, 2004.

[17] A. Sood, A. Kumar, D. K. Dhawan, and R. Sandhir, "Propensity of Withania somnifera to Attenuate Behavioural, Biochemical, and Histological Alterations in Experimental Model of Stroke", Cell. Mol. Neurobiol., pp. 1$16,2015$.

[18] R. J. Carter, J. Morton, and S. B. Dunnett, "Motor coordination and balance in rodents", Curr. Protoc. Neurosis., pp. 8-12, 2001.

[19] N. Watzman, H. Barry 3rd, W. J. Kinnard Jr, and J. P. Buckley, "Influence of certain parameters on the performance of mice on the rotarod", Arch. Int. Pharmacodyn. thérapie, vol. 169, no. 2, p. 362, 1967.

[20] B. J. Jones and D. J. Roberts, "The quantitative measurement of motor inco-ordination in naive mice using an accelerating rotarod", J. Pharm. Pharmacol., vol. 20, no. 4, pp. 302-304, 1968.

[21] H. Kuribara, Y. Higuchi, and S. Tadokoro, "Effects of central depressants on rota-rod and traction performances in mice", Jpn. J. Pharmacol., vol. 27, no. 1, pp. 117-126, 1977.

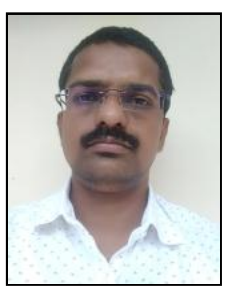

Dr. Amit S. Kamdi (03/10/1980) - a vice president Sanjeevani Multipurpose society Mul, India, a member of Red Cross Society of India. Educational Qualification:

M.D. (Pharmacology) - Mahatma Gandhi Institute of Medical Sciences (MGIMS), Sewagram, Maharashtra, India, 2017

M.P.H. (Epidemiology) - University of Alabama at Birmingham, USA, 2008

M. B. B. S. (Bachelor of Medicine \& Bachelor of Surgery) - Govt. Medical College, Nagpur, Maharashtra, India, 2004

Work Experience:

Currently working as vice president Sanjeevani Multipurpose society Mul, India.

Medical Intern

Medical Officer

Public Health Intern

Medical Officer

Vice President

Tutor Pharmacology

Assistant Professor Pharmacology

Tutor Pharmacology

Research Publications:

2005
2006
2009
$2010-2011$
$2011-2014$
$2017-2018$
$2018-2019$
$2019-2020$

[1] V. P. Gurupur, A. S. Kamdi, T. Tuncer, M. M. Tanik, and M. N. Tanju, "Enhancing medical research efficiency by using concept maps, in Software Tools and Algorithms for Biological Systems", Springer, 2011, pp. 581-588.

[2] A. S. Kamdi, N. B. Kandavalli, D. Emusu, N. Jain, M. Mamtani, and J. R. Porterfield Jr, "Weak or absent evidence for the association of HLADR antigens with risk of thyroid carcinoma: a meta-analysis of observational studies," Tissue Antigens, vol. 78, no. 5, pp. 382-389, 2011. [3] A. S. Kamdi, P. N. Bohra, S. M. Kalambe, and A. R. Chandrakapure, "The antidepressant activity of the alcoholic extract of Withania coagulans fruits in Swiss albino mice by forced swimming test," Natl. J. Physiol. Pharm. Pharmacol., vol. 9, no. 9, pp. 904-906, 2019.

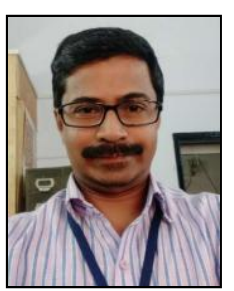

Dr. Devesh D. Gosavi (07/02/1973) - professor in pharmacology at Mahatma Gandhi Institute of Medical Sciences (MGIMS) Sevagram, India. Educational Qualification:

M. D. (Pharmacology) - Indira Gandhi Medical, College, Nagpur, Maharashtra, India, 1999.

M. B. B. S. (Bachelor of Medicine \& Bachelor of Surgery) - Govt. Medical College, Nagpur, Maharashtra, India, 1994.

Work Experience:

Currently working as Professor in Pharmacology at Mahatma Gandhi Institute of Medical Sciences (MGIMS) Sevagram, India.

Assistant lecturer in Pharmacology 1 years

Lecturer in Pharmacology 3 years

Lecturer in Pharmacology 3 years

Associate Professor in Pharmacology 4 years (app)

Professor in Pharmacology 9 years (app)

Research Publications:

[1] D. D. Gosavi, D. Sachdev, and K. Salwe, "Immunomodulatory and antioxidant effect of gomutra ark in rats," J Mahatma Gandhi Inst Med Sci, vol. 16, pp. 37-41, 2011

[2] D. O. Sachdev, D. D. Gosavi, and K. J. Salwe, "Evaluation of antidiabetic, antioxidant effect and safety profile of gomutra ark in Wistar albino rats," Anc. Sci. Life, vol. 31, no. 3, p. 84, 2012.

[3] D. D. Gosavi, A. Suman, and M. Jain, "Sodium valproate induced increased frequency of micturition and enuresis," Indian J. Pharmacol., vol. 45, no. 1, p. 87, 2013.

Other works:

[A] Dr. Gosavi, Participation as Faculty: (Guest Lectures)

1. National level trainer for NVBDCP, ICMR, New Delhi.

2. National workshop on animal experimentation and ethics

3. Workshop on recent advanses in pharmacy, IPER, Wardha.

4. Ethical issues in clinical research (RM workshop)

5. How to critisize a research article (RM workshop)

6. Genr therapy: an update, IPER Wardha

7. Guest quiz master for mumbai zonal pharma quiz.

[B] Quiz master of Zonal pharmacology quiz at MGIMS, Sewagram for 3 years.

[C] Ph.D. topic with Nagpur University, "Effect of Panchagavya ghruta on some neuropharmacological parameters in rats". 


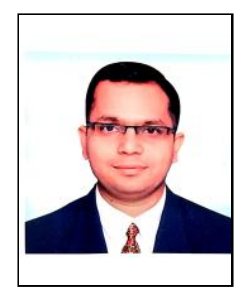

Dr. Pankaj N. Bohra (09/01/1976) - consultant pediatrician.

Educational Qualification:

D.C.H. (Paediatrics UK) RCPCH, UK, 2018.

D.C.H. (Paediatrics) CPS,Mumbai, Maharashtra, India, 2006.

M. B. B. S. RNT Medical College, Udaipur, Rajasthan,India. 2000.

Work experience:

Currently working as Consultant Pediatrician, Chinchwad, Pune-33, Maharashtra, India since 2007

Research Publications:

[1] A. S. Kamdi, P. N. Bohra, S. M. Kalambe, and A. R. Chandrakapure, "The antidepressant activity of the alcoholic extract of Withania coagulans fruits in Swiss albino mice by forced swimming test," Natl. J. Physiol. Pharm. Pharmacol., vol. 9, no. 9, pp. 904-906, 2019.

[2] S. Kokane, A. S. Kamdi, N. Kokane, and P. N. Bohra, "Study of Serum Uric Acid and BMI in Coronary Artery Disease," Int. J. Biotechnol. Biochem., vol. 15, no. 1, pp. 1-7, 2019.

[3] A. S. Kamdi, P. N. Bohra, and S. M. Kalambe, "Ofloxacin-induced maculopapular rash in the infant," Int. J. Basic Clin. Pharmacol., vol. 7, no. 11 , p. $2261,2018$. 